Syntax Literate : Jurnal Ilmiah Indonesia p-ISSN: 2541-0849

e-ISSN : 2548-1398

Vol. 5, No. 2 Februari 2020

\title{
PENYELESAIAN SENGKETA HUBUNGAN INDUSTRIAL MELALUI ARBITRASE MENURUT UU NOMOR 13 TAHUN 2003 TENTANG KETENAGAKERJAAN
}

\author{
Abdullah dan Andi Lala \\ CV. Syntax Corporation Indonesia dan Akamigas Balongan Indramayu \\ Email: Abdullahkhudori62@gmail.com dan cirebonkotakip11@gmail.com
}

\begin{abstract}
Dispute of Industrial relations can be resolved through court (litigation) and outside the court (non-litigation). The parties are free to determine an alternative settlement that will be used in settling that Dispute of Industrial Relations. The purpose of this research is to find out how the process of resolving disputes outside the legal channels or often called Alternative Dispute Resolution (ADR). This research is a type of normative juridical research, namely research that uses library sources or secondary material as a basis for research by analyzing and studying various related legal literature. In resolving disputes the problems between the two parties resolve them in a bipartite manner. However, if the bipartite settlement process is not successful and has not yet met an agreement, then the settlement can be done either by the two disputing parties or one of them is to take an alternative route in a tripartite manner consisting of mediation, conciliation, and arbitration or submit the dispute to the Industrial Relations Court which is commonly called mandatory settlement.
\end{abstract}

Keywords: Settlement of international relations, ADR and Law Number (No). 13 of 2003

\begin{abstract}
Abstrak
Perselisihan hubungan industrial bisa dibereskan lewat jalur pengadilan (litigasi) serta di luar pengadilan (non litigasi). Para pihak bebas untuk memutuskan alternatif penyelesaian yang hendak dipakai dalam menyelesaikan perselisihan Hubungan Industrial tersebut. Tujuan penelitin ini adalah untuk mengetahui bagaimana proses penyelesaian perselisihan diluar jalur hukum atau sering disebut Alternative Dispute Resolution (ADR). Penelitian ini merupakan jenis penelitian yuridis normatif, yaitu penelitian yang menggunakan sumber bahan psutaka atau sekunder sebagai bahan dasar penelitian dengan cara menganalisis dan menulusuri berbagai literatur kajian hukum yang berkaitan. Dalam menyelesaikan sengketa permasalahan kedua belah pihak menyelesaikannya dengan cara bipartit. Namun apabila proses penyelesaian secara biaprtit tidak berhasil dan belum menemui kesepakatan, maka penyelesaiannya bisa dilakukan baik oleh kedua pihak yang bersengketa atau salah satunya untuk menempuh jalur alternatif secara tripartit yang terdiri dari mediasi, konsiliasi, serta arbitrase atau dapat memberikan perselisihan tersebut kepada Pengadilan Hubungan Industrial yang lumrah dikatakan penyelesaian wajib (compulsory arbitration).
\end{abstract}




\section{Pendahuluan}

Manusia sebagai mahkluk sosial senantiasa berupaya melakukan interaksi dengan manusia lain guna memenuhi kebutuhan hidupnya, baik kebutuhan jasmani maupun kebutuhan rohani. Dalam sebuah interaksi manusia akan terjadi dua hal yaitu kesamaan dan perbedaan. Apabila yang terjadi dalam interaksi itu kesamaan-kesamaan maka akan terjadi suatu keharmonisan dalam hubungan. Namun sebaiknya apabila dalam interaksi tersebut itu terjadi perbedaan-perbedaan maka akan terjadi perselisihan atau konflik antar kedua belah pihak.

Perselisihan juga terjadi dalam dunia ketenagakerjaan, yang melibatkan yang melibatkan para pekerja. Seyogyannya perselisihan yang terjadi antara para pihak yaitu pegawai serta pengusaha tidak mesti dikhawatirkan keberadaannya, karena pada dasarnya konflik yang terjadi bisa menimbulkan dampak positif atau menguntungkan, dengan syarat para pihak yang terlibat tidak ada unsur kekerasan yang menyelimuti. Apabila perselisihan atau konflik dilandasi oleh kekerasan maka tentu akan mengundang kerugian dan permusuhan. Namun selama ini percekcokan diantara pekerja serta pengusaha banyak dijumpai sistem penyelesaiannya diwarnai dengan unsur-unsur kekerasan, anarkis, demontstrasi, mogok kerja dan sebagainya.

Sengketa hubungan industrial bisa dibereskan lewat dua jalur yaitu 1) jalur pengadilan (litigasi) dan 2) jalur luar pengadilan (non litigasi) sebagaimana diatur di dalam UU Nomor 2 Tahun 2004 Tentang Penyelesaian Perselisihan Hubungan Industrial (PPHI).

Penyelesaian sengketa yang sering terjadi banyak dijumpai cara penyelesaiannya dengan menggunakan jalur litigasi atau proses penyelesaian sengketa jalur pengadilan. Dalam kenyataanya proses yang dilalui ketika mengambil jalur pengadilan adalah tidak sesederhana yang dibayangkan. Justru proses dipengdilan ini seringkali menimblkan masalah-masalah baru sebab membutuhkan waktu yang cukup panjang dan memerlukan biaya yang tidak sedikit. Selain dari kelemahan-kelemahan yang ada berperkara melalui jalur pengadilan ini juga sangat merepotkan kaena prosesnya yang memakan waktu yang lama dan bertele-tele. Oleh karena itu penyelesaian melalui jalur pengadilan ini diketahui banyak megandung kelemahan dengan berbagai faktornya, akhirnya banyak juga orang atau para pihak yang beralih menghindari proses penyelesaian sengketa melalui jalur pengadilan dan lebih cenderung berupaya menyelesaikan permasalahannya itu melalui jalur diluar pengadilan.

Cara ini sebenarnya sudah terjadi sejak dahulu dipraktekkan ketika menyelesaikan masalah-masalah masyarakat melalui musyawarah untuk menyelesaikan pertikaian yang ada. Seiring waktu berjalan hal tersebut mulai ditingglakan ketika banyak orang berkepentingan mulai berlomba-lomba proses penyelesainya dimuka pengadilan. Baru-baru ini Masyarakat kini mulai menoleh kembali cara lama ini untuk digunakan ketika merasa proses penyelesaian sengketa dengan berbagai pertimbangan banyak mengandung kerugian dan kurang memenuhi rasa keadilan untuk kedua pihak, 
oleh sebab itu alternatif pemyelesaian ini dirasa lebih mudah dan cepat dalam prosesnya.

Undang-Undang Nomor 13 tahun 2003 tentang Ketenagakerjaan dan UndangUndang Nomor 2 Tahun 2004 tentang pemecahan persoalan Hubungan Industrial merupakan landasan dalam penyelesaian perselisihan antara pekerja dan pen gusaha. Salah satu usaha yang diharuskan dalam pemecahan persoalan itu merupakan pemecahan di luar pengadilan. Sebelum sampe ke ranah pengadilan Hubungan Industrial, masing-masing pihak yang berselisih hendkanya jangan langsung membawa kasus sengketanya ke pengadilan, tetapi diselesaikan dengan jalur mausyawarah terlebih untuk mancapai mufakat. Jalur litigasi atau pengadilan adalah jalur terakhir yang dtempuh .

Di dalam UU No. 2 Tahun 2004 tentang sistem Penyelesaian sengketa Hubungan Industrial dijelaskan bahwa sistem penyelesaian sengketa permasalahan yang terjadi antara para pihak dapat dilakukan melalui cara pengadilan. Dalam proses peyelesaian sengketa yang melalui jalur pegadilan sudah dicatat dalam system peradilan bahwa tenaga hakim telah ditambah dengan hakim Ad-Hoc, yang proses litigasinya berjalan diperadilan umum. Dalam sistem peradilan umum hanya dikenal 2 tingkat yaitu: 1) sistem peradilan di tingkat pertama dan 2) sistem peradilan tinkat kasasi. System ini diharapkan lebih efektif agar dengan cara itu Hakim dalam peradilan hubungan industrial sudah menerapkan aspek keadilan hukum terhadap kaum buruh maupun pegusaha sertapun bisa di lalui dengan jalur di luar pengadilan. Pemecahan melalui jalur di luar pengadilan bisa ditempuh dengan cara bipartit, mediasi, konsiliasi serta arbitrase.

\section{Metode Penelitian}

Penelitian ini adalah jenis penelitian doktrinal atau normatif yakni suatu proses agar menemukan aturan hukum, prinsip-prinsip hukum, ataupun doktrin-doktrin hukum supaya menjawab isu hukum permasalahan hukum yang dihadapi.

Pendekatan yuridis normatif yaitu metode pendekatan hukum dilakukan dengan cara meneliti sumber-sumber pustaka atau data sekunder sebagai bahan utama dalam penysunan data sesuai dengan kajian yang diteliti antara lain dengan menelusuri peraturan perundang undangan dan literatur-literatur bahan kajian baik buku, jurnal, makalah dan karya tulis lainya yang mendukung dan berkaitan dengan materi yang diteliti. (Soekanto \& Mamudji, 2001)

\section{Hasil dan Pembahasan}

\section{A. Pengertian Perselisihan Hubungan Industrial}

Di dalam Sosiologi kita telah mengetahui bahwa perselisihan merupakan masalah yang umum dalam kehidupan manusia, setiap interaksi tertentu akan ada reaksi. Permasalahannya apakah reaksi-reaksi tersebut dari para pihak yang berselisih dapat mengendalikannya sehingga pertemuannya dapat mencapai titik persamaan yang berdampak positif dan satu tujuan yang diharapkan. Penerimaan dari 
sekelompok manusia atas kebijakan yang telah diterima, akan berbeda-beda ada yang merasa puas ada juga yang merasa kurang puas. Tingkat kepuasan dari masingmasing juga dari para pihak berbeda-beda, sehingga hal ini yang sering menimbulkan masalah baru (Hartono, 1991).

Dalam perusahaan yang merupakan lingkungan masyarakat kerja tertentu, hubungan ketenagakerjaan tidak bisa lepas dari pengertian-pengertian di atas. Suatu kebijaksanaan pengusaha yang telah dipertimbangkan dengan matang akan diterima oleh para pekerja dengan rasa puas dan rasa kurang puas. Kelompok masyarakat yang merasa tidak puas dari hasil kebijakan tersebut biasanya akan muncul benih perselisihan antara kedua belah pihak yaitu pengusaha dengan para pekerjanya. Jika perselisihan ini berlanjut dan beritanya berkembang akan terjadi kericuhan dalam perusahaan, dimana kericuhan ini harus segera diatasi melalui jalan musyawarah mufakat. Dengan demikian, perusahaan akan dapat melangsungkan produksi sebagaimana yang telah direncanakan. Jadi, inti dari perselisihan yang terjadi dikarenakan adanya pandangan dan perasaan-perasaan yang kurang puas antara kedua pihak baik para pekerja maupun pengusaha atau perusahaan (Kartasaputra, Kartasaputra, \& Kartasaputra, 1986).

Berdasarkan kasus-kasus perselisihan industrial, penyebab utama yang sering ditemui di banyak perusahaan dapat dikelompokkan dalam empat kategori:

a) Non-normative demand, yaitu tuntutan yang tidak diatur dalam aturan hukum dan perjanjian kerjasama;

b) Normative demand, yaitu tuntutan terhadap hak-hak yang telah diatur, baik dalalm aturan perundangan atau aturan diperusahaan dalam perjanjian;

c) Keterlibatan pihak ketiga, seperti pekerja/buruh dari perusahaan lain atau serikat pekerja/serikat buruh (afiliasi lain) yang memprovokasi pekerja/buruh sehingga terjadi perselisihan; dan

d) Adanya Tekanan dari oknum pekerja setempat yang menjadi profokator penggerak timbulnya kericuhan.

Atas dasar uraian di atas, maka manusia dalam hubungan antar pribadi, tidak dapat dilepaskan dari interaksi atau hubungannya satu sama lain dalam rangka memenuhi kebutuhan/kepentingannya, baik bersifat jasmani maupun rohani. Dalam melakukan relasi bersama manusia lain telah tentu berlangsung persamaan serta perbedaan-pebedaan dalam kepentingan, pandangan, juga perbedaan itu bisa menimbulkan perselisihan, pertentangan ataupun problem.

Asyhadi mengemukakan juga pengertian perselisihan yang dilihat dari aspek psikologis, yaitu: "Perselisihan merupakan luapan emosi yang mempengaruhi hubungan seseorang dengan orang lain" (Khakim, 2003) Di dalam pada Pasal 1 angka 22 Undang-Undang Nomor 13 Tahun 2003.

Pengertian di atas bisa dipahami dengan memenuhi rasa keadilan, apakah pekerja itu merupakan kumpulan pekerja ataupun tidak, jikapun berlangsung perselisihan relasi industrial tetap memperoleh perlindungan dari Undang-Undang Nomor 13 Tahun 2003 dan Undang-Undang 2 Tahun 2004.

Dari beberapa pengertian tersebut, dapat ditarik kesimpulan unsur-unsur dari konflik/ perselisihan tersebut adalah (Husni, Atas dasar pengertian 2004) : 
a. Adanya pihak-pihak (dua orang atau lebih).

b. Masing-masing pihak memiliki tujuan yang berbeda, kehendak pihak yang satu agar kelompok lain bersikap sesuai dengan yang diinginkannya.

c. Salah satu pihak lain tidak setuju atau kehendak yang di inginkan tidak dapat dipersatukan.

Sementara itu, bentuk-bentuk perselisihan hubungan industrial pada dasarnya bisa dibagi ke dalam 2 (dua) bagian, yakni (Widodo \& Judiantoro, 1989) :

a. Perselisihan industrial menurut sifatnya:

1) Collective disputes, yaitu sengketa/perselisihan antara serikat pekerja dengan pengusaha, dikarenakan ga ada kesepahaman antar keduanya berkaitan dengan hubungan kerja, kondisi pekerjaan dan syarat-syaratnya.

2) Individual disputes, yaitu sengketa/perselisihan antara buruh yang bukan anggota serikat pekerja dengan pengusaha.

b. Perselisihan industrial menurut jenisnya:

1) Right dispute, adalah jenis perselisihan yang muncul antara kumpulan pengusaha dengan serikat pekerja/buruh dikarenakan salah satu pihak tertentu melanggar isi dari perjanjian kerjasama yang telah dibuat dan disepakati bersama.

2)Disputes of interest, yaitu pertentangan antara pengusaha/ majikan atau gabungan serikat pekerja/serikat buruh sehubungan dengan tidak adanya persesuaian pendapat mengenai syaratsyarat kerja dan/atau keadaan perburuhan.

Perselisihan antara serikat pekerja/serikat buruh ialah percekcokan diantara serikat pekerja/serikat buruh lain hanya dalam satu instansi, sebab tidak terdapatnya penyesuaian mengerti perihal keanggotaan, pengimplementasian hak dan kewajiban keserikat pekerjaan.

\section{B. Model Penyelesaian Perselisihan Hubungan Industrial dalam Hukum Ketenagakerjaan Indonesia}

Mengingat perubahan mendasar dalam UUD 1945 berkaitan dengan sistem pelaksanaan kekuasaan kehakiman, maka muncullah Undang-Undang No.48 Tahun 2009 tentang Kekuasaan Kehakiman (Indonesia, 2009). Kekuasaan kehakiman ialah kekuasaan pemerintah dalam mengatur dan menyelenggarakan sistem peradilan dalam rangka penegakan hukum yang berasaskan pancasila, demi terselenggaranya Negara Hukum Republik Indonesia. Sudah selayaknya kekuasaan kehakiman dijamin kebebebasannya dari pegaruh-pengaruh kelompok lain dalam menegakkan hukum dan dan keadilannya, karena sikap mengadili adalah sikap mulia seorang hakim dalam memutuskan perkara degan berpatokan pada sistem kejujuran, keadilan dan kebenaran yang hakiki. Oleh karena itu hal tersebut seharusnya bebas dari dampak dan tekanan orang luar dari pihak manapun (Wantjik, 1997).

Kebebasan dalam mengimplementasikan wewenang yudisial tidak mutlak sifatnya, sebab tugas dari hakim ialah menegakkan keadilan berdasarkan Pancasila dengan jalur menafsirkan serta mencari fundamental juga asas-asas yang menjadi landasannya melalui perkara-perkara yang dihadapinya, sehingga keputusannya mencerminkan perasaan keadilan bangsa dan rakyat Indonesia (Mertokusumo, 2010). 
Pasal 18 UU No. 48 Tahun 2009 menyebutkan, kekuasaan kehakiman dilaksanakan oleh sebuah Mahkamah Agung serta badan peradilan yang ada di bawahnya dalam ranah peradilan umum, peradilan militer, peradilan agama, peradilan tata usaha negara, serta oleh Mahkamah Konstitusi.

Selain dari keempat lingkungan sistem peradilan tersebut diatas, memungkinkan adanya suatu sistem pengadilan khusus yang mengiringinya. Misalnya sistem peradilan umum, dapat diadakan Pengadilan Anak, Pengadilan Niaga, Pengadilan HAM, Pengadilan Lalu Lintas, Pengadilan Ekonomi, dan Sistem Pengadilan Hubungan Industrial.

Dalam PHI termasuk sistem pengadilan special/khusus yang terdapat di area sistem peradilan umum. Seperti yang disebukan dalam Pasal 55 Undang-Undang Nomor 2 Tahun 2004, bahwa Kewenangan dari PHI ialah kewenangan yang mutlak atau kompetensi absolut dari PHI juga sebagaimna disebut dalam Pasal 56 UU No. 2 Th. 2004, bahwa PHI memiliki kewenangan untuk memeriksa dan memutus perkara:

a. Pada tingkat pertama berkaitan dengan sengketa Hak.

b. Pada tingkat pertama dan terakhir berkaitan dengan sengketa kepentingan.

c. Pada tingkat pertama berkaitan dengan sengketa pemutusan hubungan kerjasama.

d. Pada tingkat pertama dan terakhir berkaitan antar serikat pekerja/buruh di perusahan terkait.

Perselisihan hak adalah sengketa normatif yang sudah ditetapkan dalam sebuah MoU/perjanjian kerja yang telah disepakati bersama oleh kedua belah pihak yang berselisih. Maka proses penyelesaian Perselisihan Hubungan Industrial terlebih dahulu yang dilakukan adalah melalui jalur mediasi sebelum perselisihan dibawa ke ranah pengadilan. Sedangkan perselisihan jenis kepentingan adalah perselisihan terjadi dikarenakan akibat dari perbedaan pandangan tentang kondisi ketenagakerjaan yang belum diatur secara jelas dalam sebuah perjanjian kerja atau peraturan perusahaan. Perselisihan kepentingan ini terhadap tingkat pertama serta terakhir diputuskan PHI pada Pengadilan Umum (tidak dimintakan kasasi ke Mahkamah Agung), hal ini dimaksudkan untuk menjamin penyelesaian yang cepat, tepat, adil, dan murah.

Menurut UU No. 2 Tahun 2004 secara prinsip penyelesaian perselisihan hubungan industrial dapat ditempuh melalui 2 (dua) alternatif, yaitu:

a. Menyerahkan perselisihan itu secara sukarela pada seorang juru atau dewan pemisah. Proses penyelesaian jenis ini dapat juga disebut sebagai sistem pemyelesaian sukarela (voluntary arbitration), dimana perselisihan ini dapat dilakukan dengan cara mediasi, konsiliasi, dan arbitrase.

b. Menyerahkan sengketa kepada pengadilan Hubungan Industrial. Sistem penyelesaian ini disebut juga dengan sistem penyelesaian wajib (compulsory arbitration).

Secara mendasar setiap perselisihan dalam Hubungan Industrial wajib hukumnya sistem penyelesaiannya dilakukan dengan cara bipartit sebelum perselisihan itu dibawa ke pengadilan. Dari masing-masing pihak terdapat wakil pihak pengusaha dan wakil dari serikat pekerja/buruh. Wakil yang hadir dalam bipartit ditetapkan secara proporsional dan sesuai dengan kesepakatan. 
Jenis kesepakatan yang dihasilkan dari perumusan bipartit berupa persetujuan yang telah ditandatangani oleh kedua belah pihak yang berselisih. Apabila ada salah satu pihak yang tidak mau menandatangani perjanjian tersbut, maka pihak yang merasa dirugikan dapat mengajukan permohonan ke Pengadilan Hubungan Industrial di Pengadilan Negeri terdekat, walaupun tidak diatur secara khusus dalam aturan perundang-undangan.

Seandainya sistem penyelesaian secara bipartit mengalami kegagalan, maka salah satu pihak yang merasa dirugikan dapat menempuh jalur alternatif tripartit (sukarela), antara lain adalah sebagi berikut:

a. Perundingan Bipartit

Perundingan bipartit ialah perundingan diantara buruh atau serikat buruh dengan pengusaha untuk menyelesaikan perselisihan hubungan industrial. Semua bentuk perselisihan hubungan industrial bisa dibereskan lewat perundingan bipartit.

Undang-undang Nomor 2 Tahun 2004 mengharuskan tahap perundingan bipartit untuk setiap bentuk perselisihan hubungan industrial. Apabila dalam tahap ini tidak ada, maka tahap selanjutnya proses penyelesaian sengketa terebut tidak dapat ditempuh. Supaya dalam proses bipartit ini tidak memakan waktu lama dan panjang, maka hendaknya dalam peraturan perundangan dibatasi dengan waktu maksimal 30 hari. Apabila dalam kurun waktu 30 hari salah satu dari pihak menolak untuk berunding atau telah melakukan perundingan, tetapi tidak sesuai dengan kesepakatan, maka perundingan bipartitt tersebut dianggap gagal.

Jika perundingan bipartit mencapai kesepakatan penyelesaian, maka dibuat perjanjian bersama yang ditandatangani oleh para pihak. Undang-undang Nomor 2 Tahun 2004 memberikan nama formal "perjanjian bersama" untuk perjanjian antara para pihak di dalam perundingan bipartit. Perjanjian bersama yang telah didaftarkan diberikan akta bukti pendaftaran perjanjian bersama. Pasal 7 ayat (5) menegaskan bahwa jika kesepakatan bersama tidak diimplementasikan oleh salah satu pihak, sehingga pihak yang dirugikan bisa meminta permohonan eksekusi pada Pengadilan Hubungan Industrial terhadap Pengadilan Negeri di wilayah perjanjian bersama didaftar untuk memperoleh penetapan eksekusi.

Dengan demikian dapat disimpulkan ada tiga kemungkinan yang akan terjadi dalam perjanjian bipartit:

1. Terjadi perundingan dengan adanya hasil kesepakatan yang disetujui bersama

2. Terjadi perundingan dengan tidak adanya hasil kesepakatan yang diperoleh

3. Tidak terjadi perundingan antara kedua belah pihak karena kedua pihak tidak ada sama sekali terjadi perundingan dan adabila hal ini terjadi maka dapat pula disebut dengan proses bipartit yang gagal.

b. Mediasi oleh Mediator

Setiap kantor pemerintahan terdapat satu pegawai khusus yang diangkat sebagai mediator dimaksudkan untuk bertanggungjawab apabila terjadi sebuah perselisihan antara pengusaha dengan serikat pekerja. Atas keputusan dan kesepakatan bersama yang telah di setujui oleh masing-masing pihak untuk 
mengangkat pegawai khsus sebagai mediator dalam kantor pemerintahan setempat. Kemudian secara tertulis mengajukan permintaan untuk membantu menyelesaikan perselisihan yang terjadi. Dalam waktu 7 (tujuh) hari setelah menerima permintaan penyelesaian perselisihan, seorang mediator harus dapat menghimpun dan mempelajari semua kondisi dan informasi yang diperlukan dan segera ditindaklanjuti pada hari berikutnya untuk mengadakan sebuah mediasi bersama.

Apabila antara kedua pihak mencapai kesepakatan, maka kesepakatan tersbut dapat dirumuskan bersama dan kemudian ditandatangani oleh para pihak dan diketahui oleh mediator. Dan jika sebaliknya tidak terjadi kesepakatan antara kedua pihak maka pada sepuluh hari setelah sidang mediasi seorang mediator membuat surat anjuran tertulis kepada para pihak, selanjutnya setelah sepuluh hari berikutnya dari pemberian surat anjuran oleh mediator kedua belah pihak harus segera merespon dan melaporkan secara tertulis untuk memberikan keputusan akhir bahwa apakah kesepaktan itu di terima atau ditolak.

Apabila para pihak yang berelisih mendapatkan anjuran dari mediator, kemudian kesepakatan tersebut dinyatakan dalam bentuk perjanjian bersama. Dan perjanjian itu ditolak oleh salah satu pihak berselisih, kemudian pihak yang menolak menganjukan gugatan kepada Pengadilan Hubungan Industrial setempat. Untuk itu, mediator menyelesaikan dokumen yang diperlukan dalam 5 hari kerja. Dengan demikian, maka seluruh proses mediasi dapat diselesaikan paling lambat dalam waktu 40 hari kerja.

c. Konsiliasi oleh Konsiliator

Konsiliator adalah anggota masyarakat yang dianggap mempunyai kompetensi dan kemampuan dalam bidang hubungan industrial dan memahami berbagai peraturan perundangan mengenai ketenagakerjaan. Konsiliator dipilih dan ditunjuk oleh kementrian untuk melakukan konsiliasi kepada pihak-pihak yang berselisih untuk menyelesaikan permasalahan yang terjadi. Daftar konsiliator yang sudah dipilih tersedia di kantor pemerintahan ketenagakerjaan sebagai penanggungjawab. Berdsarkan kesepakatan bersama antara kedua pihak yang memilih daftar konsiliator yang sudah disediakan oleh pemerintah untuk menyelesaikan permaslahan atau sengketa mengenai pemutusan atau hubungan kerja. Sama seperti mediator seorang konsiliator bertugas menghimpun seluruh informasi yang ada dalam waktu satu minggu setelah menerima permohonan konsiliasi dan paling lambat pada hari kedelapan sudah memulai untuk konsiliasi. Dan paling lama dalam konsiliasi sudah melakukan sidang pertama dan pihak berselisih harus suda menyampaikan pernyataan dari wakil masingmasing untuk merumuskan kesepakatan bersama untuk menolak atau menerima anjuran konsiliator. Apabila salah satu pihak menolak anjuran dari konsiliator dan menggugat ke pengadilan hubungan industrial. Maka seorang konsiliator harus dapat menyelesaikan perselisihan tersebut dalam waktu maksimal 40 hari kedapan. Dalam proses konsiliasi, konsiliator dapat memanggil beberpa saksi ahli. 


\section{d. Arbitrase oleh Arbiter}

Arbitrase adalah bentuk penyelesaian sengketa hubungan industrial berdasarkan proses yudisial sebagaimana dijelaskan oleh Abdurrasyid, berikut:

"Arbitrase adalah suatu proses pemeriksaan suatu sengketa yang dilakukan secara yudisial seperti yang dikehendaki oleh para pihak yang bersengketa dan pemecahannya akan didasarkan kepada bukti-bukti yang diajukan oleh para pihak". (dalam Sudiarto \& Asyhadie, 2004)

Proses penyelesain melalui arbitrase dalam koridor masyarakat yang sadar hukum, tidak dapat dihindari muncul pelbagai prilaku yang saling tuntut menuntut satu sama yang lain, dan di masa depan yang dekat kuantitas dan kompleksitas perkara, terutama perkara-perkara ketenagakerjaan akan sangat tinggi. Metode penyelesaian sengketa lewat arbitrase menjadi gagasan dan ide yang akan digunakan untuk mengatasi dan menyelesaikan berbagai masalah yang fundamental tapi berdampak sistemik yang banyak dihadapi oleh orangorang yang berada dilingkungan ketenagakerjaan, karena berbenturan dengan tembok-tembok hukum yang kusam, kelam, kaku, dan menyeramkan.

Penyelesaian perselisihan hubungan industrial melalui arbitrase dikategorikan sebagai Alternative Dispute Resolution (ADR), adalah kehendak bebas dalam proses penyelesaian sengketa dengan menggunakan jalur non litigasi atau diluar jalur hukum negara (Margono, 2001). Penyelesaian cara ini juga diakui dalam Pasal 58, Pasal 59, dan Pasal 60 Undang-Undang Nomor 48 Tahun 2009 tentang Kekuasaan Kehakiman.38 Pasal 58 Undang-Undang Nomor 48 Tahun 2009 menyatakan, bahwa: "Usaha penyelesaian perselisihan bidang perdata dapat dilaksankan melalui jalur alternatif penyelesaian atau disebut dengan arbitrase".

Dalam praktik sengketa yang muncul diserahkan kepada masing-masing pihak, apakah akan melalui proses peradilan atau menggunakan cara penyelesaian lain, seperti arbitrase. Realitanya permasalahan perselisihan/sengketa yang terjadi dalam dunia ketenagakerjaan atau hubungan insdustrial masing-masing pihak yang bersengketa mengharapkan proses penyelesaiannya dialkukan dengan cara cepat, sederhana dan tidak mengeluarkan biaya banyak atau formal procedure and can be put in motion quickly. Dengan kata lain, jenis penyelesaian masalah ini maish dalam kategori sistem hukum yang masih dibenarkan dalam ranah hukum formal. Penyerahan kepada arbiter dinyatakan dengan surat perjanjian antara kedua belah pihak di hadapan Pegawai Kementerian Ketenagakerjaan.

Secara teoritis penyelesaian perselisihan melalui arbitrase mempunyai banyak keuntungan, di antaranya: (Charda, 2017)

1) Kerahasiaan masalah dijamin.

2) Efektif dan efisiensi waktu

3) Kedua belah pihak mengetahui kapabilitas arbiter yang dipilih, sehingga dalam proses penyelesainnya harus menganut asas-asas hokum

4) Para pihak dapat menentukan pilihan hukum untuk menyelesaikan masalahnya serta proses dan tempat penyelenggaraan arbitrase. 
5) Putusan arbitrase merupakan putusan yang mengikat para pihak (prosedur) sederhana saja ataupun langsung dapat dilaksanakan.

Arbitrase adalah penyelesaian perselisihan oleh seorang atau tiga orang arbiter yang atas kesepakatan para pihak yang berselisih diminta menyelesaikan perselisihan kepentingan, perselisihan pemutusan hubungan kerja dan perselisihan antara serikat pekerja. Pihak berselisih menunjuk tiga orang arbiter, dalam 3 (tiga) hari para pihak boleh memilih satu orang arbiter dan paling telat selama tujuah hari kerja sesudah itu, kedua arbiter tersebut dapat menunjuk seorang arbiter ketiga yang djadikan Ketua dalam Majelis Arbiter.

Apabila penyelesaian secara bipartit maupun secara tripartit (sukarela) juga gagal, maka penyelesaian perselisihan hubungan industrial dapat ditempuh melalui Pengadilan Hubungan Industrial sebagai badan atau wadah yang memberikan keadilan, sedangkan peradilan menunjukkan pada proses memberikan keadilan dalam rangka menegakkan hukum. Dalam rangka memberikan keadilan dalam penyelesaian perselisihan hubungan industrial, maka Undang-Undang Nomor 2 Tahun 2004 mengatur bentuk penyelesaian perselisihan dalam hubungan industrial yang dapat ditempuh melalui jalur Pengadilan Hubungan Industrial.

\section{Kesimpulan}

Pada prinsipnya setiap permasalahan yang terjadi dalam sengketa hubungan industrial wajib penyelesaiannya dengan cara bipartit sebelum perselsihan itu diangkat ke ranah hukum pengadilan Hubungan Industrial. Kesepakatan atau kompromi yang diinginkan dalam bipartit dinyatakan dalam bentuk perjanjian persetujuan yang ditandatangani oleh kedua pihak yang bersengketa. Apabila dalam bipartit ada salah satu pihak yang merasa dirugikan karena tidak menyepakati pernjanjian tersebut, maka pihak yang dirugikan tersebut dapat mengajukan permohonan kepada Pengadilan Hubungan Industrial di pengadilan Negeri terdekat. Walaupun tidak diatur secara khusus dalam undang-undang, serikat-serikat pekerja di perusahaan dapat membentuk forum komunikasi antar serikat pekerja.

Proses penyelesaian masalah antar serikat pekerja/buruh disarankan dengan jalur bipartit dalam kasus ini apabila para pihak yang berselisih tidak dapat menyelesaikannya dengan jalur bipartit, maka dinyatakan proses penyelesainnya gagal dan dapat ditempuh dengan alternatif jalan penyelesaian lain yaitu proses penyelesaiannya dengan menggunakan tripartit (sukarela) antara lain seperti 1) Mediasi, 2) Konsiliasi dan 3) Arbitrase atau dapat menyerahkan perselisihan itu kepada Pengadilan Hubungan Industrial yang lazim disebut penyelesaian wajib (compulsory arbitration). 


\section{BIBLIOGRAFI}

Charda, U. (2017). Model Penyelesaian Perselisihan Hubungan Industrial Dalam Hukum Ketenagakerjaan Setelah Lahirnya Undang-Undang Nomor 2 Tahun 2004. Jurnal Wawasan Yuridika, 1(1), 1-23.

Sudiarto, P. A., \& Asyhadie, Z. (2004). Mengenal Abitrase Salah Satu Alternatif Penyelesaian Sengketa Bisnis. RajaGrafindo Persada, Jakarta.

Gautama, S., \& Baru, U.-U. A. (1999). Citra Aditya Bakti. Bandung.

Hartono, C. F. G. (1991). Kapita selekta perbandingan hukum. Pt. Citra Aditya Bakti.

Husni, L. (2004). Penyelesaian perselisihan hubungan industrial melalui pengadilan \& di luar pengadilan. Divisi Buku Perguruan Tinggi, RajaGrafindo Persada.

Indonesia, R. (2009). Undang-Undang Nomor 48 Tahun 2009 Tentang Kekuasaan Kehakiman. Seketariat Negara.

Kartasaputra, G., Kartasaputra, A. G., \& Kartasaputra, R. G. (1986). Hukum perburuhan di Indonesia berlandaskan Pancasila. Bina Aksara.

Khakim, A. (2003). Pengantar hukum ketenagakerjaan Indonesia: berdasarkan Undang-Undang nomor 13 tahun 2003. Citra Aditya Bakti.

Margono, S. (2001). Pelembagaan Altenative Dispute Resolution (ADR) di Indonesia. Prospek Dan Pelaksanaan Arbitrase Di Indonesia (Mengenang Alm. Prof. Dr. Komar Kantaatmadja).

Mertokusumo, S. (2010). Hukum acara perdata Indonesia. Universitas Atma Jaya Yogyakarta.

Soekanto, S., \& Mamudji, S. (2001). Penelitian hukum normatif: Suatu tinjauan singkat. RajaGrafindo Persada.

Wantjik, K. S. (1997). Kehakiman dan Peradilan. Ghalia Indonesia, JakartaMedanSurabaya-Yogyakarta.

Widodo, H., \& Judiantoro. (1989). Segi hukum penyelesaian perselisihan perburuhan. Rajawali. 